\title{
POTENSI PENYEBARAN INFEKSI NOSOKOMIAL DI RUANGAN INSTALASI RAWAT INAP KHUSUS TUBERKULOSIS (IRINA C5) BLU RSUP PROF. DR. R. D. KANDOU MANADO
}

\author{
${ }^{1}$ Caroline Tombokan \\ ${ }^{2}$ Olivia Waworuntu \\ ${ }^{2}$ Velma Buntuan
}

\author{
${ }^{1}$ Kandidat Skripsi Fakultas Kedokteran Universitas Sam Ratulangi \\ ${ }^{2}$ Bagian Mikrobiologi Fakultas Kedokteran Universitas Sam Ratulangi \\ Email: tombokancaroline@yahoo.com
}

\begin{abstract}
Hospital is a patient service with a wide variety of different diseases. Among them are due to infectious diseases, ranging from mild to severe. This can cause a risk of transmission of infection from one patient to another, as well as with health workers who are often exposed to infectious agents. Patients with TB cases are patients with a weak immune system and also the hospitalized patients potentially exposed to nosocomial infections, it is because the patient's condition was very weak and the risk of transmission of infection is compounded when it occurs among patients. This causes pathogenic microorganisms become pathogenic. Necessary research or clinical testing in the laboratory to find out whether in a special installation space inpatient tuberculosis (IRINA C5) has a potential source of transmission of nosocomial infections. The aim of this study was to determine the source and the micro organisms that could potentially lead to the transmission of nosocomial infections in the department of Prof. IRINA C5 BLU Dr. R. D. Kandou. This study uses a prospective descriptive study. The samples studied are floor and wall treatment rooms, indoor furniture, medical equipment and the air in the department of Prof. IRINA C5 BLU Dr. RD Kandou Manado as many as 30 samples and swabs taken. The identification is done with the culture medium. On the results of the study showed 10 samples Bacillus subtilis (33.4\%), Lactobacillus sp 7 samples (23.4\%), Enterobacter agglomerans 2 samples (6.7\%), Serratia liquefaciens 2 samples (6.7\%), coccus gram negativ 2 samples (6.7\%), Staphylococcus albus 1 sample (3.4\%), Staphylococcus sp 1 sample (3.4\%), Enterobacter hafniae 1 sample (3.4\%), Streptococcus sp 1 sample $(3,4 \%)$. The conclusion of this research found most types of bacteria is Bacillus subtilis.
\end{abstract}

Keywords: Nosocomial infection, IRINA C5, bacteria

\begin{abstract}
Abstrak: Rumah Sakit merupakan tempat pelayanan pasien dengan berbagai macam penyakit yang berbeda-beda. Diantaranya merupakan penyakit karena infeksi, mulai dari ringan sampai berat. Hal ini dapat menyebabkan resiko penularan infeksi dari satu pasien ke pasien yang lainnya, begitupun dengan petugas kesehatan yang sering terpapar dengan agen infeksi. Pasien dengan kasus TBC merupakan pasien dengan daya tahan tubuh yang lemah dan juga menjadi pasien rawat inap yang berpotensi terkena penyakit infeksi nosokomial, hal ini disebabkan karena kondisi pasien yang sangat lemah dan resiko diperparah ketika terjadi penularan infeksi antar pasien. Hal ini menyebabkan mikroorganisme yang tidak patogen menjadi patogen. Diperlukan penelitian atau pengujian secara klinis di laboratorium untuk mengetahui apakah di ruang instalasi rawat inap khusus tuberkulosis (irina C5) mempunyai potensi sumber penularan infeksi nosokomial. Tujuan dari penelitian ini adalah untuk mengetahui sumber dan mikroorganisme yang berpotensi menyebabkan penularan infeksi nosokomial di IRINA C5 BLU RSUP Prof. Dr. R. D. Kandou. Penelitian ini menggunakan
\end{abstract}


metode penelitian deskriptif prospektif. Sampel yang diteliti adalah lantai dan dinding ruang perawatan, perabotan ruangan, peralatan medis dan udara di IRINA C5 BLU RSUP Prof. Dr. R. D. Kandou Manado sebanyak 30 sampel dan diambil secara usapan. Identifikasi dilakukan dengan media kultur. Pada hasil penelitian menunjukkan Bacillus subtilis 10 sampe (33,4\%), Lactobacillus sp 7 sampel (23,4\%), Enterobacter agglomerans 2 sampel (6,7\%), Serratia liquefaciens 2 sampel (6,7\%), Kokus gram negativ 2 sampel (6,7\%), Staphylococcus albus 1 sampel (3,4\%), Staphylococcus sp 1 sampel (3,4\%), Enterobacter hafniae 1 sampel (3,4\%), Streptococcus sp 1 sampel (3,4\%). Kesimpulan pada penelitian ini jenis bakteri terbanyak ditemukan adalah Bacillus subtilis.

Kata kunci: Infeksi nosokomial, IRINA C5, bakteri.

Rumah sakit adalah tempat untuk mencari kesembuhan tetapi bisa juga merupakan sumber dari berbagai penyakit, yamg berasal dari penderita maupun dari pengunjung yang berstatus karier. Kuman penyakit ini dapat hidup dan berkembang di lingkungan rumah sakit, seperti udara, air, lantai, makanan, perabotan rumah sakit dan peralatan medis maupun non medis. Permasalahan Infeksi Nosokomial atau juga dikenal dengan nama Hospital Acquired Infection (HAI) atau yang dikenal dengan sebutan nosocomion dalam bahasa yunani, nosos yang artinya penyakit dan komeo yang artinya merawat. Jadi infeksi nosokomial dapat diartikan sebagai infeksi yang terjadi di rumah sakit dan menyerang penderita - penderita yang sedang dalam proses asuhan keperawatan. Survei prevalensi yang dilakukan oleh World Health Organization (WHO) di 55 rumah sakit dari 14 negara yang mewakili 4 wilayah kerja WHO (Eropa, Mediterania, Asia Tenggara dan Pasifik Barat) menunjukkan rata-rata $8,7 \%$ dari pasien yang dirawat di rumah sakit mengalami infeksi nosokomial dan frekuensi tertinggi infeksi nosokomial dilaporkan dari rumah sakit di Asia Tenggara dengan prevalensi $11 \%$. Setiap saat, lebih dari 1,4 juta orang di seluruh dunia menderita bukan hanya dari penyakit dasarnya melainkan juga dari komplikasi infeksi yang diperoleh dari rumah sakit. Tingkat infeksi yang lebih tinggi ditemukan pada pasien dengan peningkatan kerentanan karena faktor usia tua, sementara dalam kemoterapi dan faktor penyakit kronis yang mendasari sehingga mengganggu sistem kekebalan tubuh pasien termasuk pasien Tuberkulosis. Tuberkulosis (TB) masih menjadi masalah kesehatan dunia yang sangat penting terbukti dengan dimasukkannya penyakit ini sebagai salah satu fokus dari program Millenium Development Goals (MDGs). Pada tahun 2013 sesuai dengan laporan dari World Health Organization (WHO) diperkirakan 9,0 juta orang hidup dengan Tuberkulosis dan 1,5 juta orang meninggal karena penyakit ini. Walaupun program penanggulangan penyakit Tuberkulosis sudah dijalankan sejak tahun 1992 namun saat ini belum didapatkan hasil yang memuaskan. Bahkan bebannya bertambah dengan munculnya TB resisten OAT (MDR TB), TB anak, TB-HIV dan TB dengan penyulit seperti infeksi nosokomial. ${ }^{1-6}$ Berbagai hal dan kondisi tersebut menjadi landasan utama untuk melatar belakangi untuk melakukan penelitian tentang potensi sumber penularan infeksinosokomial di ruangan rawat inapkhusus Tuberkulosis (IRINA C5) di RS Prof. Dr. R.D Kandou Manado.

\section{METODE PENELITIAN}

Penelitian yang dilakukan bersifat deskriptif prospektif. Penelitian ini dilakukan dari bulan Januari 2015 sampai Maret 2015. Sampel pada penelitian ini berjumlah 30 yang diambil dari ruangan perawatan yaitu dinding dan lantai, perabotan ruangan yaitu tempat tidur,buffet, dan kursi, peralatan medis (nasal kanul, tabung oksigen,tiang infus), dan Udara. Pengelolaan sampel dilakukan 
Jurnal e-Biomedik (eBm), Volume 4, Nomor 1, Januari-Juni 2016

di Laboratorium Mikrobiologi Fakultas nosokomial di Irina C5 ruangan rawat inap Kedokteran Unsrat. khusus Tuberkulosis BLU RSUP Prof.Dr.R.D. Kandou Manado. Sampel

\section{HASIL PENELITIAN}

Pada kesempatan ini, telah dilakukan penelitian sumber penularan infeksi yang di ambil berjumlah 30 sampel. Pengambilan sampel diuraikan dalam tabel berikut

TABEL 1. Uraian Pengambilan Sampel

\begin{tabular}{|l|l|c|}
\hline \multicolumn{1}{|c|}{ Kategori } & \multicolumn{1}{|c|}{ Sampel } & $\begin{array}{l}\text { Jumlah } \\
\text { Sampel }\end{array}$ \\
\hline Ruang Perawatan & Lantai, dinding & 9 \\
\hline Perabotan ruangan & $\begin{array}{l}\text { Tempat tidur, } \\
\text { buffet, kursi }\end{array}$ & 6 \\
\hline Peralatan medis & $\begin{array}{l}\text { Nasal kanul, tiang } \\
\text { infus, tabung } \\
\text { oksigen }\end{array}$ & 7 \\
\hline Udara & Pagi, Siang & 8 \\
\hline Total & \multicolumn{2}{|l}{30} \\
\hline
\end{tabular}

TABEL 2. Distribusi Pertumbuhan Bakteri

\begin{tabular}{|c|c|c|c|}
\hline \multicolumn{1}{|c|}{ Media } & \multicolumn{1}{|c|}{$\begin{array}{c}\text { Nutrien } \\
\text { Agar }\end{array}$} & $\begin{array}{c}\text { Mac } \\
\text { Conkey }\end{array}$ & Agar darah \\
\hline Ada pertumbuhan & 30 & 16 & 21 \\
\hline $\begin{array}{l}\text { Tidak ada } \\
\text { pertumbuhan }\end{array}$ & - & 14 & 9 \\
\hline \multicolumn{1}{|c|}{ Total } & 30 & 30 & 30 \\
\hline
\end{tabular}

TABEL 3. Hasil Pewarnaan Gram

\begin{tabular}{|l|c|c|}
\hline Pewarnaan Gram & Jumlah Sampel & Persentase (\%) \\
\hline Gram Positif & 20 & 66,7 \\
\hline Gram Negatif & 5 & 16,7 \\
\hline Gram Positif dan Negatif & 5 & 16,7 \\
\hline Total & 30 & 100 \\
\hline
\end{tabular}


Tombokan, Waworuntu, Buntuan: Potensi penyebaran infeksi nosokomial ...

TABEL 4. Hasil Distribusi Bakteri

\begin{tabular}{|l|c|c|}
\hline Mikroorganisme & Jumlah & Persentase (\%) \\
\hline Bacillus subtilis & 10 & 33,4 \\
\hline Staphylococcus albus & 1 & 3,4 \\
\hline Staphylococcus sp. & 1 & 3,4 \\
\hline Streptococcus sp. & 1 & 3,4 \\
\hline Lactobacillus sp. & 7 & 23,4 \\
\hline Enterobacter cloacae & 3 & 10 \\
\hline Enterobacter agglomerans & 2 & 6,7 \\
\hline Enterobacter hafniae & 1 & 3,4 \\
\hline Serratia liquefaciens & 2 & 6,7 \\
\hline Kokus gram negatif & 2 & 6,7 \\
\hline Total & 30 & 100 \\
\hline
\end{tabular}

TABEL 5. Hasil identifikasi Bakteri Kategori Ruangan Perawatan

\begin{tabular}{|c|c|c|}
\hline Bakteri & Jumlah & Persentase \\
& $(\%)$ \\
\hline Bacillus subtilis & 6 & 54,5 \\
\hline Serratia liquefaciens & 1 & 9,0 \\
\hline Lactobacillus sp. & 2 & 18,1 \\
\hline Enterobacter cloacae & 1 & 9,0 \\
\hline Kokus gram negativ & 1 & 9,0 \\
\hline Total & 11 & 100 \\
\hline
\end{tabular}

TABEL 6. Hasil Identifikasi Bakteri Kategori Perabotan Ruangan

\begin{tabular}{|l|c|c|}
\hline Bakteri & Jumlah & Persentase (\%) \\
\hline Bacillus subtilis & 3 & 60 \\
\hline $\begin{array}{l}\text { Staphylococcus } \\
\text { sp. }\end{array}$ & 1 & 20 \\
\hline $\begin{array}{l}\text { Kokus gram } \\
\text { negative }\end{array}$ & 1 & 20 \\
\hline Total & 5 & 100 \\
\hline
\end{tabular}


Jurnal e-Biomedik (eBm), Volume 4, Nomor 1, Januari-Juni 2016

TABEL 7. Hasil Identifikasi Bakteri Kategori Peralatan Medis

\begin{tabular}{|c|c|c|}
\hline Mikroorganisme & Jumlah & Persentase (\%) \\
\hline Lactobacillus sp. & 4 & 66,6 \\
\hline Staphylococcus albus & 1 & 16,6 \\
\hline Bacillus subtilis & 1 & 16,6 \\
\hline Total & 6 & 100 \\
\hline
\end{tabular}

TABEL 8. Hasil Identifikasi Bakteri di Udara

\begin{tabular}{|c|c|c|}
\hline \multicolumn{1}{|c|}{ Bakteri } & Jumlah & Persentase \\
\hline $\begin{array}{c}\text { Enterobacter } \\
\text { cloacae }\end{array}$ & 2 & 25 \\
\hline $\begin{array}{c}\text { Lactobacillus sp. } \\
\text { Serratia } \\
\text { liquefaciens }\end{array}$ & 1 & 12,5 \\
\hline $\begin{array}{l}\text { Enterobacter } \\
\text { agglomerans }\end{array}$ & 1 & 12,5 \\
\hline $\begin{array}{c}\text { Enterobacter } \\
\text { hafniae }\end{array}$ & 1 & 12,5 \\
\hline Streptococcus sp. & 8 & 12,5 \\
\hline Total & 100 \\
\hline
\end{tabular}

\section{BAHASAN}

Hasil identifikasi bakteri ditemukan 10 spesies bakteri, yaitu Bacillus subtilis yang merupakan bakteri terbanyak yang ditemukan sebanyak 10 sampel $(33,4 \%)$, Lactobacillus sp. ditemukan sebanyak 7 sampel (23,4\%), Enterobacter cloacae ditemukan sebanyak 3 sampel (10\%), Enterobacter agglomerans ditemukan sebanyak 2 sampel (6,7\%), Serratia liquefaciens ditemukan sebanyak 2 sampel (6,7\%), Kokus Gram negatif ditemukan sebanyak 2 sampel (6,7\%), Staphylococcus albus ditemukan sebanyak 1 sampel (3,4\%), Staphylococcus sp. ditemukan sebanyak 1 sampel (3,4\%), Enterobacter hafniae ditemukan sebanyak 1 sampel (3,4\%), dan Streptococcus sp. ditemukan sebanyak 1 sampel (3,4\%). Bakteri Bacillus subtilis adalah bakteri paling banyak ditemukan pada penelitian ini dengan jumlah 10 sampel. Bakteri ini termasuk batang besar aerob dan non-patogenik. Bacillus subtilis dapat ditemukan di tanah,air,dan udara ${ }^{27}$.

Lactobacillus sp. adalah bakteri gram positif, dan bersifar non-patogenik bakteri ini mampu memproduksi asam laktat dan karbohidrat $^{13}$. Enterobacter cloacae merupakan bakteri yang terdapat pada feses,tanah,air. bakteri ini dapat 
menyebabkan pneumonia nosokomial pada pasien yang system kekebalan tubuhnya sudah melemah ${ }^{25}$. Pontea agglomerans berpotensi pathogen dalam menyebabkan berbagai infeksi,pada penelitian yang dilakukan oleh RS St Charles di London,dalam jurnal RS tersebut dijelaskan bahwa bakteri ini merupakan penyebab primer dari pnemonia ${ }^{26}$ Serratia liquefaciens merupakan bakteri gram negative yang dapat menyebabkan pneumonia,bakteremia,dan endokarditis ${ }^{27}$. Kokus Gram negatif merupakan genus insekta dari family Coccidae ${ }^{25}$. Staphylococcus albus terdapat pada kulit manusia,saluran pernapasan,dan saluran pencernaan. Bakteri ini merupakan penyebab dari infeksi kulit yang disertai pembentukan abses ${ }^{13}$. Staphylococcus $s p$. terdapat pada kulit dan selaput lender pada manusia, bakteri ini dapat menyebabkan infeksi pada manusia ${ }^{13}$. Enterobacter hafniae adalah bakteri batang gram negatif ditemukan pada feses,tanah,air ${ }^{25}$ bakteri ini dapat menyebabkan infeksi nosokomial berhubungan dengan penyakit gastrointestinal,penyakit yang berhubungan dengan luka, pneumonia, dan bakteremia dari saluran urogenital ${ }^{28}$.

Streptococcus sp. merupakan bakteri gram positif dan dapat menyebabkan penyakit endemic antara lain radang tenggorokan, scarlet fever, erisepelas ${ }^{14}$.

\section{SIMPULAN}

Berdasarkan hasil penelitian potensi penyebaran infeksi nosokomial di Ruangan Instalasi Rawat Inap Khusus Tuberkulosis (irina C5) BLU RSUP PROF. DR. R. D. Kandou Manado periode Januari 2015 Maret 2015 maka dapat disimpulkan sebagai berikut :

1. Pemeriksaan bakteri pada 30 sampel ditemukan semua sampel menunjukkan pertumbuhan bakteri. 20 sampel bakteri gram positif, 5 bakteri gram negatif, 5 bakteri gram positif dan negatif.

2. Total bakteri yang didapat dari 30 sampel sebanyak 10 jenis bakteri Baccilis subtulis yang merupakan bakteri paling banyak ditemukan.
3. Sumber yang berpotensi menyebabkan infeksi nosocomial terdapat pada ruang perawatan, alat medis, dan udara.

\section{DAFTAR PUSTAKA}

1. Ducel G, Fabry J, Nicole L. Prevention of Hospital Acquired Infections, A Practical Guide, 2nd edition, WHO, 2002.

2. Fauci A, Kasper D, Longo D, Braunwald E et al. Harrison's Principles of Internal Medicine. 17th ed. McGraw Hill. New York, 2008.

3. Sudoyo A W, Setiyohadi B, Alwi I, Setiati S. Ilmu Penyakit Dalam. Edisi V. Jakarta. 2009. Hal 2907

4. Burke JP. Infection Control - A problem for Patient Safety. The New England Journal of Medicine. 348:7; 651 - 656 .

5. World Health Organization. Global Tuberculosis Report 2014. WHO.

6. Clean Care is Safer Care Team. Report on the burden of endemic health care-associated infection worldwide. Geneva: World Health Organization Press; 2011.

7. Brouwer M, Coelho E, Dores Mosse Cd, Brondi L, Winterton L, et al. Healthcare Workers' Challenges in the Implementation of Tuberculosis Infection Prevention and Control Measures in Mozambique. PLoS ONE 9(12): e114364. doi:10.1371/journal. pone. 0114364. 2014

8. Departemen Kesehatan (DepKes) Republik Indonesia, 1995. Cara Penularan Infeksi Nosokomial. Jakarta. www.depkes.go.id

9. Brooks GF, Butel JS, Morse SA. Mikrobiologi Kedokteran. Edisi 23. Jakarta,2008.

10. Jawetz, Melnick, Adelberg. Mikrobiologi Kedokteran Ed 23. Jakarta Penerbit Buku Kedokteran EGC, 2007.

11. Ginting Mardan. Infeksi Nosokomial dan manfaat Pelatihan 
Keterampilan Perawat terhadap Pengendaliannya di Ruang Rawat Inap Penyakit Dalam RSUP $\mathrm{H}$. Adam Malik Medan Tahun 2001. Poltekkes Medan, 2001.

12. Staf Pengajar Fakultas Kedokteran Universitas Indonesia. Buku Ajar Mikrobiologi Kedokteran. Jakarta: Penerbit Binarupa Aksaea,1994.

13. Tagoe DNA, Baidoo SE, Dadzie I, Tengey D, Agede C. Potensial Sources Of Transmission Of Hospital Acquired Infections In The Volta Regional Hospital in Ghana. Ghana Medical Journal, 2011;1(45).

14. Joshi R, Reingold AL, Menzies D, Pai M. Tuberculosis among health-care workers in low- and middle- income countries: A systemic review. PLOS MED 3(12): e494. doi: 10.1371/journal.

15. Klevens RM, Edward JR, Richards CL Jr., et al. Estimating healthcare- associated infections and deaths in U.S. hospitals, 2002. Public Health Rep.2007;122(2):160-166.

16. Manzies D, Pai M, Joshi R. Risk of Tuberculosis Infection and disease associated with work in health care settings. Int J Tuber Lung Dis 11(6): 593-605.2007.

17. WHO, Kemenkes, PPI. Pedoman Pencegahan dan Pengendalian Infeksi di Rumah Sakit dan Fasilitas Pelayanan Kesehatan Lainnya.2008.

18. Departemen Kesehatan (DepKes) Republik Indonesia, 1995. Cara Penularan Infeksi Nosokomial. Jakarta. www.depkes.go.id

19. Tjien, dkk. 2004. Panduan Pencegahan Infeksi Untuk Fasilitas Pelayanan Kesehatan dan Sumber Daya Terbatas. Jakarta: Yayasan Bina Pustaka Sarwono Prawirohardjo.

20. Darmaji, 2008. Infeksi Nosokomial dan Pengendalian. Salemba Medika, Jakarta.
21. Ducel G, Hygie F, Geneva, Switzerland. Prevantion of hospital-acquired infections. A Practical Guide. Ed.2. Hal 4-10

22. Setio H, Rohani. Panduan Praktik Keperawatan. Jakarta.2010. Hal 811

23. KEPUTUSAN

MENTERI KESEHATAN REPUBLIK INDONESIA Nomor 1204/MENKES/SK/X/2004.

Tentang Persyaratan Kesehatan Lingkungan Rumah Sakit.

24. W.A Newman Dorland. Kamus kedokteran Dorland Ed 29. Jakarta: Penerbit Buku Kedokteran EGC,2002.

25. S AL-Damluji, CM Dickinson, A Beck. "Enterobacter agglomerans: a new case of primary Pneumonia”. Jurnal St Charles Hospital London.1982;37:865-6.

26. Jawetz, Melnick, Adelberg. Mikrobiologi kedokteran. Edisi ke 23. Jakarta. EGC,2007

27. Jamela Ghadban Auda Al-Grawi. Hafnia Alvei Urinary Tract Infection. Jurnal Collage Of Medicine University Of Baghdad.

28. Darmadi. (2008). Infeksi Nosokomial: Problematika dan pengendaliannya. Jakarta: Salemba Medika.

29. Kowalski, J. W. (2007). AirTreatment System for Controlling Hospital Acquired infections. New York: Immune Buiding System Inc.

30. Tennat, I., Harding, H. Microbial Isolates from Patients in An Intensive Care Unit, and Associated Risk Factors. West Indian Medical Journal. 2005;54(4).

31. Taher TM., Golestanpour A. (2009). Symptomatic Nosocomial Urinary Tract Infection in ICU Patients: Identification of Antimicrobial Resistance Pattern. Iranian Journal of Clinical Infectious Disease. Vol. 4,P. 25-29 
Tombokan, Waworuntu, Buntuan: Potensi penyebaran infeksi nosokomial ... 